\title{
Lumen
}

Selected Proceedings from the Canadian Society for Eighteenth-Century Studies

\section{The Hunting Ideal, Animal Rights, and Feminism in Northanger Abbey and Sense and Sensibility}

\section{Barbara K. Seeber}

Volume 23, 2004

URI : https://id.erudit.org/iderudit/1012200ar

DOI : https://doi.org/10.7202/1012200ar

Aller au sommaire du numéro

Éditeur(s)

Canadian Society for Eighteenth-Century Studies / Société canadienne d'étude du dix-huitième siècle

ISSN

1209-3696 (imprimé)

1927-8284 (numérique)

Découvrir la revue

Citer cet article

Seeber, B. K. (2004). The Hunting Ideal, Animal Rights, and Feminism in Northanger Abbey and Sense and Sensibility. Lumen, 23, 295-308.

https://doi.org/10.7202/1012200ar

Copyright (C Canadian Society for Eighteenth-Century Studies / Sociéte canadienne d'étude du dix-huitième siècle, 2004
Ce document est protégé par la loi sur le droit d'auteur. L'utilisation des services d'Érudit (y compris la reproduction) est assujettie à sa politique d'utilisation que vous pouvez consulter en ligne.

https://apropos.erudit.org/fr/usagers/politique-dutilisation/ 


\title{
16. The Hunting Ideal, Animal Rights, and Feminism in Northanger Abbey and Sense and Sensibility
}

\author{
Women and animals are similarly positioned in a patriarchal world, as ob- \\ jects rather than subjects. \\ It was such a dead time of year, no wild-fowl, no game, and the Lady \\ Frasers were not in the country. ${ }^{1}$
}

Hunting was as controversial a sport in the eighteenth century as it is today. While rural sports were contested and defended from a variety of perspectives, this essay focuses on the emerging discourse of animal rights in the eighteenth century and its relationship to the representations of hunting in Jane Austen. Texts by Humphrey Primatt and William Cowper emphasize the sentience of animals and charge hunters with unnecessary cruelty. Primatt argues that the 'hunting out for sport and destruction creatures of the tamer kind' cannot be 'justifi[ied].' For Cowper, the 'detested sport / ... owes its pleasures to another's pain' and 'feeds upon the sobs and dying shrieks / Of harmless nature. ${ }^{2} \mathrm{We}$ can be certain that Austen was aware of Cowper's views for he was her favorite poet, and while biographer Claire Tomalin claims that Austen 'kept quiet about Cowper's detestation of field sports' out of loyalty to

1 Carol J. Adams, The Sexual Politics of Meat: A Feminist-Vegetarian Critical Theory (New York: Continuum Press, 1990), p. 168. Jane Austen, Northanger Abbey, vol. 5 of The Novels of Jane Austen, ed. R.W. Chapman (Oxford: Oxford University Press, 1988), p. 209. All subsequent references are to this edition of the novel.

2 Humphrey Primatt, A Dissertation on the Duty of Mercy and Sin of Cruelty to Brute Animals, vol. 3 of Animal Rights and Souls in the Eighteenth Century, ed. Aaron Garrett (Bristol: Thoemmes Press, 2000), p. 62. William Cowper, The Task, in vol. 2 of The Poems of William Cowper, eds. John D. Baird and Charles Ryskamp (Oxford: Clarendon Press, 1995), 3:326-29. All subsequent references are to this edition of the poem and references are to book and line. 
her brothers who did hunt, the novels tell another story. ${ }^{3}$ The representations of hunting in Northanger Abbey and Sense and Sensibility are hardly positive. Male characters who are avid hunters are satirized for their love of the sport and, by comparing their hunting of animals and their treatment of women, Austen inflects the anti-hunting argument with a feminist purpose. Indeed, as Christine Kenyon-Jones demonstrates, 'In the late eighteenth century ... the association of animals with oppressed human groups moved out of the purely symbolic realm and became much more direct' and 'the issue of animal cruelty became associated with questions of rights and citizenship. ${ }^{4}$ Northanger Abbey and Sense and Sensibility demystify the hunting ideal and draw a parallel between the position of women and animals within patriarchy.

As Stephen Deuchar explains, the hunting ideal was articulated partly as a response to critiques of hunting. Its central elements were that 'rural sport was healthy, virtuous, brought beneficial contact with nature, provided either a restorative rest from work or an admirable substitute for it, was royal, noble, manly and even patriotic.' This was especially the case at the end of the century, argues Deuchar, when the threat of the French Revolution and its jacobin politics led to a resurgence of the sporting ideal. A renewed emphasis was placed on the English 'country sportsmen's robust physical health, warlike capabilities, hospitality, national loyalty and personal generosity.' David C. Itzkowitz similarly states that hunting 'became associated with the hardy virtues' of country life, 'believed to be excellent training for war,' and seen as 'conducive to manliness. ${ }^{5}$ Austen's depictions of hunting deviate from these idealizing patterns in striking ways, and seem to have more in common with anti-hunting texts. Rural sports were attacked as leading to gambling,

3 Claire Tomalin, Jane Austen: A Life (New York: Knopf, 1997), p. 137. Also see Patricia Jo Kulisheck, 'Every Body Does Not Hunt,' Persuasions 8 (1986): p. 20-24. While I agree with her general point that hunting is 'associated with characters who behave improperly' (p. 23), our approaches are very much different. Kulisheck underestimates the predominance of the hunting pattern. Many more male characters in Austen hunt besides those identified by her, nor is it confined to the seducers. Austen consistently links hunting to patriarchal privilege - which is in possession of the villains and the heroes alike.

4 Christine Kenyon-Jones, Kindred Brutes: Animals in Romantic-Period Writing (Aldershot: Ashgate, 2001), p. 40.

5 Stephen Deuchar, Sporting Art in Eighteenth-Century England: A Social and Political History (New Haven: Yale University Press, 1988), p. 57, 155. David C. Itzkowitz, Peculiar Privilege: A Social History of English Foxhunting, 1753-1885 (Hassocks: Harvester Press, 1977), p. 20, 21. 
sexual vice, and moral decay in general. Certain sports such as foxhunting were perceived as dangerous by blurring class distinctions, and others as causing social unrest because of their exclusive nature and the divisiveness of the Game Laws. Concern for animals and anti-cruelty arguments also were articulated, most notably by Humphrey Primatt and William Cowper.

Humphrey Primatt has been cited as 'one of the most important figures in the development of a notion of animal rights' and as one of the first to present an 'alternative to the concept of a merely indirect obligation towards animals. ${ }^{6} \mathrm{He}$ is concerned with the lives of animals in their own right - not just because animal cruelty might later lead to cruelty towards humans (the well-known narrative captured in Hogarth's The Four Stages of Cruelty). In A Dissertation on the Duty of Mercy and Sin of Cruelty to Brute Animals (first published in 1776 and reprinted in the 1820s), he argues that 'a man can have no natural right to abuse and torment a beast, merely because a beast has not the mental powers of man.' He dethrones reason as the central determinant of human-animal relations, and, instead, emphasizes the commonality of sentience: 'Pain is pain, whether it be inflicted on man or on beast.' The ability to feel pain entitles animals to 'FOOD, REST, and TENDER USAGE,' but 'not only their necessary Wants, and what is absolutely their Demand on the principles of strict Justice, but also their Ease and Comfort, and what they have a reasonable and equitable Claim to, on the principles of Mercy and Compassion.' Animals, according to Primatt, have a right to 'Happiness. ${ }^{7}$ While critics such as Robert Malcolmson have suggested that anti-cruelty campaigns focused on the activities of the lower classes, Primatt's text does not bear out the reading that all anti-cruelty arguments mask or intersect with social regulation and 'concern for effective labour discipline,' for he draws attention to cruelty across class lines: ${ }^{8}$

I am aware of the obloquy to which every man must expose himself, who presumes to encounter Prejudice and long received Customs. To make a compari-

6 Aaron Garrett, introduction to Animal Rights and Souls in the Eighteenth Century, 6 vols. (Bristol: Thoemmes, 2000), 1: p. xix. Andreas Holger Maehle, 'Cruelty and Kindness to the "Brute Creation": Stability and Change in the Ethics of the Man-Animal Relationship, 1600-1850,' in Animals and Human Society: Changing Perspectives, eds. Aubrey Manning and James Serpell (London: Routledge, 1994), p. 94.

7 Primatt, p. 12, 7, 147, 202.

8 Robert W. Malcolmson, Popular Recreations in English Society, 1700-1850 (Cambridge: Cambridge University Press, 1973), p. 89. 
son between a Man and a Brute, is abominable: To talk of a man's Duty to his Horse or his Ox, is absurd; To suppose it is a Sin to chace a Stag, to hunt a Fox, or course a Hare, is unpolite; To esteem it barbarous to throw at a Cock, to bait a Bull, to roast a Lobster, or to crimp a Fish, is ridiculous. Reflections of this kind must be expected.

The specific examples cover a wide range: from the agricultural to the domestic; and from sports associated with the lower classes (bull-baiting) to the aristocratic stag hunt. Primatt emphasizes that he seeks to protest the activities of 'the Obstinate, the Hard-hearted, and the Ignorant, of every class and denomination. ${ }^{9}$ Nor is he alone in his attack on hunting on the grounds of animal cruelty. In The Cry of Nature; Or, An Appeal to Mercy and to Justice, on Behalf of the Persecuted Animals (1791), John Oswald argues for vegetarianism and claims that hunting 'irritate[s] the baneful passions of the soul; her vagabond votaries delight in blood, in rapine, and devastation.' For Primatt and Oswald, animal suffering matters in and of itself, but it is also seen as intersecting with other forms of oppression. Primatt protests human slavery alongside animal suffering: 'the white man (notwithstanding the barbarity of custom and prejudice) can have no right ... to enslave and tyrannize over a black man. ${ }^{\prime \prime}$

Cowper's The Task (1785) similarly denounces hunting: animals 'suffer torture' (6.390) to 'make ... [man] sport, / To gratify the frenzy of his wrath, / Or his base gluttony' (6.386-88). It is the hunter's 'supreme delight / To fill with riot, and defile with blood' (3.306-07) the 'scenes form'd for contemplation, and to nurse / The growing seeds of wisdom' (3.301-02). Like Primatt, Cowper sees animals as capable of 'suffer[ing] torture' (6.390), and he empathizes with their pain and pleasure:

The heart is hard in nature, and unfit

For human fellowship, as being void

Of sympathy, and therefore dead alike

To love and friendship both, that is not pleased

With sight of animals enjoying life,

Nor feels their happiness augment his own. (6.321-26)

9 Primatt, p. 75-76, 77.

10 John Oswald, The Cry of Nature; Or, An Appeal to Mercy and to Justice, on Behalf of the Persecuted Animals (London: J. Johnson, 1791), p. 16-17. Primatt, p. 11. 
The poet imagines an animal world freed from hunting and human control, where the bounding fawn ... darts across the glade / When none pursues, through mere delight of heart, / And spirits buoyant with excess of glee' (6.327-29) and the horse 'skims the spacious meadow at full speed, / Then stops and snorts, and, throwing high his heels, / Starts to the voluntary race again' (6.330-33). Hunting is also a concern in Cowper's prose. In an essay published in The Gentleman's Magazine, he 'describe[s]' his three pet hares, Puss, Tiney, and Bess, 'as having each a character of his own' in an attempt to represent the lives of animals otherwise treated simply as unindividuated objects: 'We know indeed that the hare is good to hunt and good to eat, but in all other respects poor Puss is a neglected subject.' After observing and recording the individual behavior patterns of the three animals, Cowper concludes, 'my intimate acquaintance with these specimens of the kind has taught me to hold the sportsman's amusement in abhorrence; he little knows what amiable creatures he persecutes, of what gratitude they are capable, how cheerful they are in their spirits, what enjoyment they have of life, and that, impressed as they seem with a peculiar dread of man, it is only because man gives them peculiar cause for it. ${ }^{11}$ Donna Landry dismisses Cowper's view of hunting as self-serving - his 'advocacy ends with inviting the benevolent ... to feel pleased with themselves' - and faults him for keeping pets. Landry's project is to uncover 'a long, if now largely forgotten, tradition linking hunting and conservation' and while she claims that 'this book is not so much a defense of modern fox-hunting as an enquiry into its history,' her bias is readily apparent: 'If hunting were more widely understood by its supporters as well as by its critics, in its full historical complexity - social, animal and ecological - I strongly suspect that most people, even if they had no wish to take part, might agree that a ban was unnecessary. ${ }^{, 12}$ To maintain her argument that hunting was and continues to be good for the countryside, Landry consistently downplays the importance of anti-hunting arguments in the eighteenth century, relegating the history of radical vegetarianism to a mere footnote and trivializing Cowper. Austen, however, took Cowper very seriously. The 'Biographical Notice of the Author' states that

11 William Cowper, The Gentleman's Magazine, June 1784, in vol. 5 of The Letters and Prose Writings of William Cowper, eds. James King and Charles Ryskamp (Oxford:Clarendon Press, 1986), p. 42, 40, 43. For a discussion of Cowper's identification with animals, see David Perkins, 'Cowper's Hares,' Eighteenth-Century Life 20, no. 2 (1996): p. 57-69.

12 Donna Landry, The Invention of the Countryside: Hunting, Walking and Ecology in English Literature, 1671-1831 (Houndmills: Palgrave, 2001), p. 124, xvii, xv, xviii-xx. 
Austen's 'favourite moral writers were Johnson in prose, and Cowper in verse,' and in the Memoir, J. E. Austen Leigh records: 'Amongst her favourite writers, Johnson in prose, Crabbe in verse, and Cowper in both, stood high. ${ }^{13}$ Cowper's influence can be seen in Austen's characterization of hunters.

In Northanger Abbey, Austen clearly demystifies the hunting ideal. The character of John Thorpe belies the notion that hunting 'strengthen[s] the mind, intellectually and morally as well as the body' as defenders of the sport claimed it did. ${ }^{14} \mathrm{He}$ is first introduced to us as a 'most knowinglooking coachman' driving along 'with all the vehemence that could most fitly endanger the lives of himself, his companion, and his horse' (p. 44). When he boasts to Catherine that he 'never read[s] novels; I have something else to do' (p. 48), that 'something else' turns out to be horse-riding and hunting:

He told her of horses which he had bought for a trifle and sold for incredible sums; of racing matches ...; of shooting parties, in which he had killed more birds (though without having one good shot) than all his companions together; and described to her some famous day's sport, with the foxhounds, in which his foresight and skill in directing the dogs had repaired the mistakes of the most experienced huntsman, and in which the boldness of his riding, though it had never endangered his own life for a moment, had been constantly leading others in difficulties, which he calmly concluded had broken the necks of many.

Catherine 'could not entirely repress a doubt' of John Thorpe 'being altogether completely agreeable' (p. 66). Throughout Northanger Abbey, Thorpe is the subject of satire. The physical prowess boasted by the hunting ideal is undercut: Thorpe 'was a stout young man of middling height' with 'a plain face and ungraceful form' (p. 45). The intellectual benefit of hunting also is thrown into doubt. He is fond of drinking 'There is not the hundredth part of the wine consumed in this kingdom, that there ought to be. Our foggy climate wants help' - and his oratory skills sadly lacking, he relies on 'exclamations, amounting almost to

13 Henry Austen, 'Biographical Notice of the Author,' in vol. 5 of The Novels of Jane Austen, ed. R.W. Chapman (Oxford: Oxford University Press, 1988), p. 7. James Edward Austen-Leigh, Memoir of Jane Austen (Oxford: Clarendon Press, 1963), p. 89. For Austen's allusions to Cowper in her letters and novels, see John Halperin's 'The Worlds of Emma: Jane Austen and Cowper,' Jane Austen: Bicentenary Essays, ed. John Halperin (Cambridge: Cambridge University Press, 1975), p. 197-206.

14 Itzkowitz, p. 21. 
oaths' (p. 64) and frequent use of 'Oh! d- ' (p. 46). And, of course, he is a prolific boaster. Catherine has to bear 'the effusions of his endless conceit' (p. 66): 'she readily echoed whatever he chose to assert, and it was finally settled between them without any difficulty, that his equipage was altogether the most complete of its kind in England, his carriage the neatest, his horse the best goer, and himself the best coachman' (p. 65). When Thorpe boasts about his riding skill, he wishes to bolster his sense of dominance. He assures Catherine that his horse 'will soon know his master' (p. 62). It is telling that the first time that Thorpe appears on the scene, he is associated with cruelty towards animals: 'the horse was immediately checked with a violence which almost threw him on his haunches' (p. 44). Catherine appears to be more sensitive to his horse than he is. When he asks her if she 'did ... ever see an animal so made for speed,' Catherine responds dryly, 'He does look very hot to be sure' (p. 46). Perhaps Austen here drew on Cowper's portrait of the rider who 'clamorous in praise / Of the poor brute, seems wisely to suppose / The honours of his matchless horse his own' (6.436-38). When Thorpe promptly suggests another outing after an already extensive excursion, Catherine objects, 'but will not your horse want rest?' to which he replies, 'Rest! ... all nonsense; nothing ruins horses so much as rest; nothing knocks them up so soon' (p. 47-48).

Austen's portrait of John Thorpe suggests the parallel positioning of women and animals within patriarchal structures. Thorpe would like to master Catherine the way he does his horse. When Catherine wants to honour her engagement with the Tilneys, Thorpe deceives her, and when she wants to get out of the carriage, he 'only lashed his horse into a brisker trot' leaving Catherine with 'no power of getting away, [and] obliged to ... submit' (p. 87). At this point, both Catherine and the horse are at his mercy. That the parallel exists in John Thorpe's mind is evident when Catherine 'broke away and hurried off': "'She is as obstinate as -." Thorpe never finished the simile, for it could hardly have been a proper one' (p. 101). Thorpe views both women and animals as objects of value. His pursuit of Catherine is entirely motivated by mistaken notions of her wealth. And when he boasts about his horses, it is about the value they have, rather than any kind of affective bond he might have with them: 'Look at his forehand; look at his loins; only see how he moves; that horse cannot go less than ten miles an hour' (p. 46). General Tilney's remark that 'It was such a dead time of year, no wild-fowl, no game, and the Lady Frasers were not in the country' (p. 209) is revealing, as the grammar of the list makes an ideological point about the parallel position of women and animals. And the sentence's irony plays with the differing perspectives of hunter and prey: it may be a 'dead time' for the hunter, but surely not the animals! 
In a text which vindicates the novel genre and its readers, Thorpe's preference of hunting to reading hardly recommends the sport. Moreover, given that Northanger Abbey's vindication of novel reading is gendered, defending women writers and women readers, John Thorpe's avowed disdain for reading Burney's Camilla, for example, also reveals his misogyny. The novel's hero is delineated in sharp contrast to Thorpe. Henry Tilney confidently asserts that 'the person, be it gentleman or lady, who has not pleasure in a good novel, must be intolerably stupid' (p. 106). When riding in a curricle under his direction, Catherine is pleasantly surprised: 'Henry drove so well, - so quietly - without making any disturbance, without parading to her, or swearing at them; so different from the only gentleman-coachman whom it was in her power to compare him with' (p. 157). The fact that he does not 'swear' at the horses distinguishes Henry from Thorpe in his treatment of animals: Henry is not associated with cruelty towards animals, while the latter is. While the text does imply that Henry hunts, he does not make it a topic of conversation and 'weary' (p.76) Catherine, nor is he shown as actively engaging in it. The only textual reference to his hunting is a description of his room as 'strewed with his litter of books, guns, and great coats' (p. 183); significantly, the presence of guns is balanced by the presence of books.

In Sense and Sensibility, Austen delivers another comic portrait which belies the hunting ideal. Sir John Middleton, a 'sportsman,' is characterized by his love for hunting, on the one hand, and, on the other, a 'shameless' and 'total want of talent and taste. ${ }^{15}$ During Marianne's musical performance, he 'was loud in his admiration at the end of every song, and as loud in his conversation with the others while every song lasted' (p. 35). His understanding of people reveals a similar lack of refinement: Willoughby is 'as good a kind of fellow as ever lived' and 'a very decent $\operatorname{shot}^{\prime}$ (p. 43). When prodded by the impatient Marianne 'is that all you can say for him?' (p. 43) - he elaborates: 'he is a pleasant, good-humoured fellow, and has got the nicest little black bitch of a pointer I ever saw' (p. 44). If the hunting ideal emphasized hospitality and generosity, Sir John possesses these qualities with a vengeance. Austen makes clear that there is a self-serving motive underlying his generosity: a family party is to be avoided at all costs. And it is not long before the Dashwood women experience his hospitality as oppressive: as Marianne puts it, "The rent of this cottage is said to be low; but we

15 Jane Austen, Sense and Sensibility, vol. 1 of The Novels of Jane Austen, ed. R.W. Chapman (Oxford: Oxford University Press, 1988), p. 32, 35, 32. All subsequent references are to this edition of the novel. 
have it on very hard terms, if we are to dine at the park whenever anyone is staying with them, or with us' (p. 109). While he may be endlessly generous with his company, there are limits when it comes to the more material. He does charge rent to his impoverished female relatives, and is possessive of his hunting grounds:

In shewing kindness to his cousins therefore he had the real satisfaction of a good heart; and in settling a family of females only in his cottage, he had all the satisfaction of a sportsman; for a sportsman, though he esteems only those of his sex who are sportsmen likewise, is not often desirous of encouraging their taste by admitting them to residence within his own manor. (p. 33)

Putting the 'satisfaction of a good heart' and 'the satisfaction of a sportsman' in opposition with each other, the passage comes close to echoing Cowper's characterization of the hunter as having a 'heart ... hard in nature' (6.321). Moreover, as Margaret Anne Doody comments, Austen sets up hunters in 'opposition' and 'antagonism' to mothers: ${ }^{16}$ Sir John Middleton 'was a sportsman, Lady Middleton a mother. He hunted and shot, and she humoured her children; and these were their only resources' (p. 32).

Austen's characterization of Willoughby initially appears to uphold the hunting ideal. He enters the novel as 'a gentleman carrying a gun, with two pointers playing round him' (p.42), and his identity as a hunter is stressed throughout. His 'manly beauty' is emphasized: Marianne 'soon found out that of all manly dresses a shooting-jacket was the most becoming' (p. 43). He is a man of action in his rescue of Marianne; he 'offered his services, and perceiving that her modesty declined what her situation rendered necessary, took her up in his arms without farther delay, and carried her down the hill' and 'then departed, to make himself still more interesting, in the midst of an heavy rain' (p. 42). Margaret thinks of Willoughby as 'Marianne's preserver' but Austen is sure to undercut this glamorized view as 'more elegan[t] than precis[e]' (p. 46). And, most significantly in contrast to Thorpe and Middleton, he is eloquent and a great reader. In short, he is 'equal to what ... [Marianne's] fancy had ever drawn for the hero of a favourite story' (p. 43). Of course, Willoughby is too good to be true. His love of books, for one, is suspect:

16 Margaret Anne Doody, introduction to Sense and Sensibility, by Jane Austen (Oxford: Oxford University Press, 1990), p. xxix. 
[Marianne] proceeded to question him on the subject of books; her favourite authors were brought forward and dwelt upon with so rapturous a delight, that any young man of five and twenty must have been insensible indeed, not to become an immediate convert to the excellence of such works, however disregarded before. Their taste was strikingly alike. The same books, the same passages were idolized by each - or if any difference appeared, any objection arose, it lasted no longer than till the force of her arguments and the brightness of her eyes could be displayed. He acquiesced in all her decisions, caught all her enthusiasm. (p. 47)

Willoughby is more sensible to female charms than literary ones. His admiration of Cowper (p. 47) particularly rings false given the poet's stance on hunting. It is interesting that in an earlier passage, Marianne Dashwood is disappointed by Edward's 'tame' and 'spiritless' (p. 17) reading: 'if he is not to be animated by Cowper!' (p. 18). Jane Austen does not specify the particular poem in question. Emma Thompson and Ang Lee's film adaptation shows Edward reading from Cowper's 'The CastAway,' and Doody suggests possible allusions to the 'critique of slavery,' the 'praise of liberty' or the 'sense of the divine in nature' found in The Task. ${ }^{17}$ Yet, it is also possible that the passage in question was anti-hunting, especially since later on in the book, it is Edward Ferrars who points out that 'every body does not hunt' (p. 91). In Willoughby, Austen presents and discredits the hunting ideal as a facade, a deception which seduces Marianne. Animals are not the only prey for Willoughby. His dalliance with Marianne is the most pointed example in Sense and Sensibility of the parallel between the hunting of animals and hunting of women. ${ }^{18}$ He pursues both for his 'own amusement' (p. 320). And while Willoughby feels 'a pang' for Marianne, 'he lived to exert, and frequently to enjoy himself' and 'in his breed of horses and dogs, and in sporting of every kind, he found no inconsiderable degree of domestic felicity' (p. 379).

Mr and Mrs John Dashwood's excursion with their son Harry 'to see the wild beasts at Exeter Exchange' (p. 221) moves hunting to a global scale; during Austen's time, Exeter housed 'crocodiles, ostriches, kanga-

17 Emma Thompson, Sense and Sensibility: The Screenplay and Diaries (London: Bloomsbury, 1995), p. 50. Doody, p. xvii.

18 For a discussion of Henry Crawford in this light, see Barbara K. Seeber's 'Nature, Animals, and Gender in Mansfield Park and Emma,' LIT: Literature Interpretation Theory 13, no.4 (2002): p. 269-285. Also see Gracia Fay Ellwood's "'Such a Dead Silence": Cultural Evil, Challenge, Deliberate Evil, and Metanoia in Mansfield Park,' Persuasions On-Line 24, no. 1 (2003). 
roos, elephants, rhinoceroses, toucans and birds of paradise amongst the more mundane collection of monkeys.' As Randy Malamud states, the zoo is 'fundamentally a construct of imperial culture': it 'acts as both a model of empire (where humanity holds dominion over lesser species arrayed for our pleasure, our betterment, our use) and simultaneously as a metaphor for the larger, more important imperial enterprises in the sociopolitical hierarchy amid which it flourishes. ${ }^{19}$ In the eighteenth century, zoos habitually exhibited humans from colonized parts of the world alongside animals, and, hence, in very concrete terms asserted not only human dominion over animals, but also English dominion over colonized peoples, naturalizing the latter by equating it with the former. It is telling, I think, that Austen credits Mr and Mrs John Dashwood easily the most repellent characters in the book - with the visit to the zoo. It suggests Austen's awareness that the way we treat animals tells us a lot about other social hierarchies. Her focus is on gender relations, but the detail of the zoo draws attention to the interconnectedness of hierarchies of species, race, and class. The possession of animals marks privilege, whether it be locally (the Dashwood women must give up their horses when expelled from Norland) or nationally. The Dashwoods are aptly named in that regard; as Doody has pointed out, they 'seem to bear an autumnal name, to be leaves dashed from the wood. ${ }^{20}$ While Rosmarie Bodenheimer considers Marianne's admiration of nature simply as a subject of Austen's parody, Marianne's emotional identification with the landscape makes a point about women and nature occupying similar ideological positions. ${ }^{21}$ Austen's novel lends itself to an ecofeminist perspective, such as that by Carol J. Adams, quoted in this essay's epigraph. ${ }^{22}$ And although Elinor may tease Marianne's 'passion for dead

19 John H. Plumb, 'The Acceptance of Modernity,' in The Birth of a Consumer Society: The Commercialization of Eighteenth-Century England, eds. Neil McKendrick, John Brewer, and John H. Plumb (London: Hutchinson, 1982), p. 323. Randy Malamud, Reading Zoos: Representations of Animals and Captivity (New York: New York University Press, 1998), p. 59.

20 Doody, p. xl.

21 Rosmarie Bodenheimer, 'Looking at the Landscape in Jane Austen,' Studies in English Literature 21, no. 4 (1981): p. 605-23. Also see Jonathan Bate, The Song of the Earth (London: Picador, 2000).

22 Also see Animals \& Women: Feminist Theoretical Explorations, eds. Carol J. Adams and Josephine Donovan (Durham: Duke University Press, 1995) and a special issue dedicated to 'Ecological Feminism,' Hypatia: A Journal of Feminist Philosophy 6, no.1 (1991). 
leaves' (p. 88), she, too, feels 'provocation' and 'censure' when she hears from her brother that Norland's 'old walnut trees are all come down to make room' for a hothouse (p. 226).

Northanger Abbey's John Thorpe, whose character is defined by his passion for hunting and his ignorance of books, is an early example of a type present in many of Austen's novels. In Mansfield Park, Maria Bertram is 'doomed to the repeated details' of Mr. Rushworth's 'day [of] sport, good or bad, his boast of his dogs, ... and his zeal after poachers.' We can infer that Mr. Rushworth, like John Thorpe, is not a great reader: he struggles with his 'two and forty speeches' in the rehearsing of Lovers' Vows. And in Persuasion, Charles Musgrove 'did nothing with much zeal, but sport; and his time was otherwise trifled away, without benefit from books, or any thing else. ${ }^{23}$ Captain Benwick, in contrast, is 'a reading man' (p. 182): 'Give him a book, and he will read all day long' (p. 132). Consistent with Austen's opposition of reading and hunting, Benwick does not hunt. This abstinence causes considerable anxiety in his acquaintance. Mary Musgrove believes him to be 'a very odd young man':

I do not know what he would be at. We asked him to come home with us for a day or two; Charles undertook to give him some shooting, and he seemed quite delighted, and for my part, I thought it was all settled; when behold! on Tuesday night, he made a very awkward sort of excuse; "he never shot" and he had "been quite misunderstood." (p. 130)

Charles suspects he only wanted to come to Uppercross to talk to Anne of books and once he discovered she would not be there, abandoned his plan: 'His head is full of some books that he is reading upon your recommendation, and he wants to talk to you about them; he has found out something or other in one of them which he thinks - Oh! I cannot pretend to remember it, but it was something very fine' (p. 131). Admiral Croft feels that Benwick's 'soft sort of manner does not do him justice' (p. 171) and finds his manner 'rather too piano for me' (p. 172). At the end of the novel, we do hear of Benwick 'rat-hunting' at Uppercross with Charles, but we only have Charles's word for it that it was an enjoyable activity: 'We had a famous set-to at rat-hunting all the morning, in my father's great barns; and he played his part so well, that I have liked him

23 Jane Austen, Mansfield Park, vol. 3 of The Novels of Jane Austen, ed. R.W. Chapman (Oxford: Oxford University Press, 1988), p. 115, 139. Jane Austen, Persuasion, vol. 5 of The Novels of Jane Austen, ed. R.W. Chapman (Oxford: Oxford University Press, 1988), p. 43. All subsequent references are to this edition of the novel. 
the better ever since' (p. 219). The notion of 'playing his part' suggests that Benwick is merely acting a role in order to get along with his new brother-in-law; Austen underscores the role of hunting in the social construction of gender.

While it is true that some women did participate in the hunt in the eighteenth century, the activity clearly divides men and women in Austen's novels. ${ }^{24}$ There are no female hunters in Austen's fiction, and only Mrs. Bennet and Lydia in Pride and Prejudice speak with enthusiasm about the sport. Lydia's boasts about her 'dear Wickham' are worthy of John Thorpe's self-promotion: 'no one was to be put in competition with him. He did every thing best in the world; and she was sure he would kill more birds on the first of September, than any body else in the country.' And Mrs. Bennet, delirious at the renewed prospect of Jane's marriage to Mr. Bingley and his 'four or five thousand a year,' enthusiastically offers him any inducement she can think of: 'When you have killed all your own birds, Mr. Bingley [...] I beg you will come here, and shoot as many as you please, on Mr. Bennet's manor. I am sure he will be vastly happy to oblige you, and will save all the best of the covies for you.' While Mrs. Bennet and her daughter uncritically internalize the hunting ideal, Austen's letter to her sister Cassandra expresses ironic detachment:

Edward and Fly [Frank] went out yesterday very early in a couple of Shooting Jackets, and came home like a couple of Bad Shots, for they killed nothing at all. They are out again today, \& are not yet returned - Delightful Sport! — They are just come home; Edward with his two Brace, Frank with his Two and a half. What amiable Young Men! ${ }^{25}$

The description emphasizes the separation of the gendered spheres: the men experience the outdoors; the women are confined to the indoor space of 'home.' Overall, the description rings with irony. The sport is hardly 'delightful' to her - she cannot participate in it. Nor does she employ euphemistic language - the sport's success is boldly announced

24 For discussion of women hunters, see Landry's The Invention of the Countryside: Hunting, Walking and Ecology in English Literature, 1671-1831 and Betty Rizzo's 'Equivocations of Gender and Rank: Eighteenth-Century Sporting Women,' Eighteenth-Century Life 26, no.1 (2002): p. 70-93.

25 Jane Austen, Pride and Prejudice, vol. 2 of The Novels of Jane Austen, ed. R.W. Chapman (Oxford: Oxford University Press, 1998), p.318, 4, 337. Jane Austen, Jane Austen's Letters, ed. Deirdre Le Faye (Oxford: Oxford University Press, 1995), p. 10. 
as 'killing' - hardly an attribute of 'amiable' behavior! Cowper's influence on Austen is evident in her representations of hunting. Moreover, she develops his critique from a feminist perspective: women, in Austen's world, do not hunt; rather they are hunted.

BARBARA K. SEEBER

Brock University 